\title{
PEMILIHAN UMUM MENURUT HUKUM ISLAM
}

\author{
Sodikin \\ Fakultas Hukum Universitas Muhammadiyah Jakarta \\ Jl. KH. Ahmad Dahlan, Cirendeu, Ciputat \\ E-mail: sodikinsadali68@gmail.com
}

\begin{abstract}
General Election in Islamic Law. This article discuss the implementating general election in Islamic law, both the legislative elections, elections of regional heads and presidential elections. Indonesian elections in accordance with the mechanism of the western democracies, so that the election is the only way in choosing representatives and leaders. In the Islamic view of the elections is not the only way but one of the ways to choose a government or leader. Elections according to the Islamic view of the law may permissible, but must be in accordance with the implementation of sharia, not using a mechanical cause many western democracies not helpful.
\end{abstract}

Abstract: general election, Islamic law, democracy

\begin{abstract}
Abstrak. Pemilihan Umum Menurut Hukum Islam. Tulisan ini menjelaskan tentang pelaksanaan pemilihan umum menurut hukum Islam, baik pemilu legislatif, kepala daerah maupun presiden. Pelaksanaan pemilu di Indonesia sesuai dengan mekanisme demokrasi Barat sehingga pemilu merupakan satu-satunya cara dalam memilih wakil rakyat maupun pemimpin. Dalam pandangan Islam, pemilu bukan merupakan satu-satunya cara tetapi salah satu cara yang dilakukan untuk memilih wakil rakyat atau pemimpin. Pemilu menurut pandangan Islam hukumnya boleh atau mubah, tetapi pelaksanaannya harus sesuai ketentuan syariah, tidak menggunakan mekanisme demokrasi Barat yang banyak menimbulkan kemudaratan.
\end{abstract}

Kata kunci: pemilihan umum, hukum Islam, demokrasi

\section{Pendahuluan}

Pemilihan umum, yang kemudian dikenal dengan pemilu, dalam demokrasi Barat merupakan salah satu implementasi dari kedaulatan rakyat, sehingga apa pun alasannya agar hak-hak rakyat dapat disalurkan maka pemilulah yang harus diselenggarakan. Hiruk pikuk penyelenggaraan pemilu di Indonesia, baik pemilu kepala daerah, legislatif maupun presiden dan wakil presiden, dilaksanakan dalam rangka untuk memenuhi kedaulatan rakyat yang merupakan suatu praktek ketatanegaraan untuk mengisi jabatan publik. Perdebatan panjang mengenai RUU pemilihan kepala daerah yang kemudian hasil sidang paripurna DPR mengesahkan pemilihan kepada daerah melalui DPRD juga merupakan alasan dalam rangka untuk mengimplementasikan kedaulatan rakyat yang dimaksud. Oleh karena pelaksanaan pemilu tersebut merupakan amanat yang dikandung dalam Undang-Undang Dasar Negara Republik Indonesia Tahun 1945, maka pemilu yang merupakan praktek ketatanegaraan yang

Naskah diterima: 27 Februari 2015, direvisi: 25 November 2015, disetujui untuk terbit: 4 Desember 2014. harus dilaksanakan. Pemilu selain implementasi dari kedaulatan rakyat, juga pemilu dilaksanakan sebagai pemenuhan hak-hak asasi manusia, juga pemilu dilaksanakan sebagai penggantian pejabat negara secara teratur. Akan tetapi, setiap pemilu yang diselenggarakan selalu menimbulkan masalah, dan terjadi sengketa antara peserta pemilu maupun dengan penyelenggara pemilu. Pemilu yang diselenggarakan membutuhkan biaya yang sangat mahal, baik biaya sosial maupun dana yang berasal dari anggaran negara/daerah. Konflik yang terjadi setelah pemilu dilaksanakan, karena ada pihak yang merasa tidak puas dengan hasil yang diperoleh. Wakil-wakil rakyat yang terpilih juga belum tentu menghasilkan wakil yang membawa amanah, justru wakil yang dipilih adalah para koruptor, baik anggota legislatif maupun kepala daerah. Apabila melihat realita demikian, maka pemilu yang dilaksanakan di Indonesia banyak menimbulkan mudarat daripada manfaat yang diperoleh.

Mayoritas penduduk Indonesia beragama Islam dan agama Islam harus menjadi bagian dalam kehidupannya, termasuk di dalamnya adalah bagaimana cara memilih pemimpin. Agama Islam (termasuk hukumnya) tidak 
memberikan batasan untuk memilih metode tertentu dalam memilih wakil rakyat atau pemimpinnya. Hal ini dikarena dalam Islam (Hukum Islam) mempunyai tujuan yang agung yaitu agar tidak ada kesulitan ( bagi kaum muslimin. Dengan demikian, umat dapat memilih pemimpinnya (wakil rakyat, kepala daerah maupun presiden) mereka berdasarkan metode yang sejalan dengan tuntutan zaman, tempat dan waktu selama tidak keluar dari batas syariat.

Sebenarnya terjadi perbedaan pendapat di antara ulama atau fukaha dalam hal praktek pemilu, khususnya yang dipraktekkan di Indonesia maupun di dunia lain. Ada yang menyatakan bahwa pemilu adalah salah satu, bukan satu-satunya cara (uslûb), yang bisa digunakan untuk memilih para wakil rakyat yang duduk di majelis perwakilan atau untuk memilih penguasa. Sebagai salah satu cara, dalam pandangan Islam, tentu saja pemilu ini tidak wajib ${ }^{1}$. Menurut pendapat ini tentu saja perlu dicari cara lain yang sesuai dengan syariat. Islam memberikan alternatif dalam pemilihan wakil rakyat yang akan duduk di majelis perwakilan maupun memilih penguasa untuk memimpin rakyatnya. Syariat tidak menentukan sistem apa yang digunakan, tetapi Islam memberikan pedoman dalam kehidupan bernegara. Agama Islam itu nasihat sebagaimana Rasulullah Saw bersabda: "Agama itu nasihat. "Kami bertanya: "Untuk siapa ya Rasulullah?" Beliau menjawab: "Untuk Allah, Kitab-Nya, Rasul-Nya, para pemimpin kaum muslimin dan mereka semuanya (kaum muslim)". (H.r. Muslim dari Tamîm al-Dârî).

Hadits tersebut menunjukkan agar umat dalam setiap perbuatannya dapat dipertanggungjawabkan di hadapan Allah Swt., termasuk dalam melaksanakan pemilu. Sebagaimana dijelaskan dalam Alquran:

Dan sesungguhnya Kami telah menciptakan manusia dan mengetahui apa yang dibisikkan oleh hatinya. Kami lebih dekat kepadanya daripada urat lehernya. (yaitu) ketika dua malaikat mencatat amal perbuatannya, yang satu duduk di sebelah kanan dan yang lain duduk di sebelah kiri. Tiada suatu ucapan pun yang diucapkannya, melainkan ada didekatnya malaikat pengawas yang selalu hadir. (Q.s. Qâf [50]: 16-18)

Allah Swt. telah menurunkan syariat untuk mengatur kehidupan umat manusia (rakyat), sehingga diterima atau tidaknya pertanggungjawaban tersebut ditentukan dengan syariat. Apabila sesuai dengan syariat, maka akan diterima, sebaliknya apabila tidak sesuai maka akan ditolak, sebagaimana Sabda Nabi Saw. bahwa siapa saja yang melakukan amal perbuatan yang tidak

${ }^{1}$ Dikutip dari Buletin Dakwah, Al-Islam, "Untuk Kita Renungkan”, Hizbut Tahrir Indonesia, Edisi 701 Tahun XIX 11 Jumadil Akhir 1435 H/11 April 2014 M. sesuai dengan tuntutan syariat maka perbuatan itu akan tertolak. (H.r. Muslim). Begitu juga dalam pelaksanaan pemilu di Indonesia, harus dilihat apakah sudah sesuai dengan syariat atau belum.

\section{Hakikat Kedaulatan Rakyat}

Berbicara kedaulatan rakyat berarti membicarakan tentang kekuasaan yang tertinggi ada pada rakyat sebagaimana dikemukakan di atas. Untuk mengimplementasikan kedaulatan rakyat maka harus dilaksanakan dengan pemilihan. Pemilihan semacam ini sebagai wujud dari demokrasi perwakilan yang dikenal selama ini, karena tidak mungkin semua rakyat dapat memimpin sehingga perlunya perwakilan umat/rakyat sebagai aspirasi rakyat.

Kata "kedaulatan" berasal dari bahasa Arab, yaitu dawlah atau dûlah, dalam kamus al-Zurjawî dikatakan bahwa secara harfiah dîlah atau dawlah berarti "putaran atau giliran"2. Kata dawlah memiliki dua bentuk yaitu pertama, dûlatan yang berarti beredar. Istilah ini dihubungkan dengan adanya larangan peredaran kekayaan hanya di antara orang kaya. Kedua, nudâwiluhâ yang berarti mempergantikan. Istilah ini berkaitan dengan adanya penegasan bahwa kekuasaan merupakan sesuatu yang harus digilirkan di antara umat $^{3}$. Menurut sejarah peradaban Islam, kata dawlah dipergunakan untuk menunjuk pada pengertian rezim kekuasaan, seperti Daulah Bani Umayyah dan Daulah Bani 'Abbasiyyah ${ }^{4}$. Masdar Farid Mas'udi menyatakan:
Kedaulatan sebagai konsep kekuasaan (sovereignty) untuk mengatur kehidupan ada yang bersifat terbatas (muqayyad), relatif (nisbî) dan ada yang tidak terbatas (ghayr muqayad) atau mutlak (absout). Kedaulatan absolut adalah kedaulatan atas semua kedaulatan yang tidak dibatasi oleh kedaulatan pihak lain. Kedaulatan absolut hanya milik Allah Swt., untuk mengatur alam semesta melalui hukum alam-Nya dan mengatur kehidupan manusia melalui sinyal-sinyal hukum moral yang diilhamkan kepada setiap nurani (qalb) manusia atau diwahyukan melalui para nabi dan rasul-Nya, sedangkan dalam negara sebagai bangunan sosial dan proyek peradaban yang direkayasa oleh manusia dalam wilayah tertentu yang berdaulat adalah manusia secara kolektif sebagai khalifah-Nya ${ }^{5}$.

Makna kedaulatan dapat ditemukan dalam Alquran antara lain Q.s. Âli 'Imrân [3]: 26 yang artinya "Katakanlah: Wahai Tuhan Yang mempunyai

\footnotetext{
${ }^{2}$ Masdar Farid Mas'udi, Syarah Konstitusi UUD 1945 dalam Perspektif Islam, (Jakarta: Alvabet, 2010), h. 46.

${ }^{3}$ Jimly Asshiddiqie, "Bung Hatta: Bapak Kedaulatan Rakyat", dalam Bung Hatta Bapak Kedaulatan Rakyat, Editor: Sri Edi Swasono, (Jakarta: Yayasan Bung Hatta, 2002), h. 87.

${ }^{4}$ Jimly Asshiddiqie, Islam dan Kedaulatan Rakyat, (Jakarta: Gema Insani Press, 1995), Cet. Pertama, h. 87.

${ }^{5}$ Masdar Farid Mas'udi, Syarah Konstitusi UUD 1945, h. 47.
} 
kerajaan..." ${ }^{\prime 6}$ Dalam tafsir dan kajian yang lain terhadap ayat tersebut ada pula yang menerjemahkan sebagai "Katakanlah Hai Tuhan Yang memiliki (sekalian) Kekuasaan,..." . Ada juga yang mengartikan "Ia, Allah Tuhan yang berdaulat..."

Selanjutnya kata "rakyat" diartikan dengan segenap penduduk suatu negara (sebagai imbangan pemerintahan) ${ }^{9}$. Dalam bahasa Inggris diartikan dengan people, sedangkan dalam bahasa Arab dijumpai kata raiyyah yang mengacu pada pengertian masyarakat (rakyat). Pada dasarnya setiap negara akhirnya akan berbicara tentang rakyat, dan rakyat pada suatu negara adalah pemegang kekuasaan, artinya rakyat menjadi sumber kekuasaan dalam arti relatif. Moh. Hatta menyatakan bahwa kedaulatan rakyat berarti pemerintahan rayat yang dilakukan oleh para pemimpin yang dipercaya oleh rakyat. Dengan sendirinya di kemudian hari pimpinan pemerintahan di pusat dan daerah jatuh ke tangan pemimpin-pemimpin rakyat ${ }^{10}$.

Pemahaman tentang rakyat dalam kedaulatan rakyat berarti kekuasaan tertinggi ada pada rakyat dan menempatkan kekuasaan tertinggi ada pada rakyat. Ajaran kedaulatan rakyat sebagai ajaran yang terakhir dipraktekkan pada negara-negara modern mendapatkan tempat yang baik, karena ajaran kedaulatan rakyat dapat dianggap sebagai ajaran yang terbaik selain ajaran kedaulatan yang lainnya. Oleh karena rakyat berdaulat atau berkuasa, maka segala aturan dan kekuasaan yang dijalankan oleh negara tidak boleh bertentangan dengan kehendak rakyat. Menurut ajaran ini, rakyat berdaulat dan berkuasa untuk menentukan bagaimana rakyat diperintah dalam rangka mencapai tujuan negara. Ajaran ini dipraktekkan pada negara-negara Barat yang bersifat individualistis karena menempatkan rakyat sebagai sesuatu yang tinggi, sehingga menurut mereka suara rakyat adalah suara Tuhan. Akan tetapi dalam ajaran Islam bukan berarti rakyat yang berkuasa, tetapi ada hak Allah yang harus didahulukan, sehingga setiap peraturan perundang-undangan atau hukum harus sesuai syariat.

Seorang tokoh dan intelektual muslim, yaitu Kasman Singodimedjo menyatakan bahwa:

\footnotetext{
${ }^{6}$ Kementerian Urusan Agama Islam, Wakaf, Da'wah dan Irsyad Kerajaan Saudi Arabia, Al Qur'an dan Terjemahannya, (Medina AlMunawwarah: Percetakan Raja Fahd, 1418), h. 79.

${ }^{7}$ A. Hassan, Al Furqon (Tafsir Al Qur'an), (Jakarta: Tinta Mas, 1962), h. 103.

${ }^{8}$ Salim Azzam, Beberapa Pandangan Tentang Pemerintahan Islam, (Bandung: Mizan, 1983), h. 80.

${ }^{9}$ Departemen Pendidikan dan Kebudayaan Republik Indonesia, Kamus Besar Bahasa Indonesia, (Jakarta: Balai Pustaka, 1991) h. 722.

${ }^{10}$ Mohammad Hatta, Demokrasi Kita, (Jakarta:Ghalia Indonesia, 1977), h. 89.
}

Karena rakyat atau umat itu selalu terdiri atas mausiamanusia, dan karena manusia itu sebagai makhluk selalui daif atau lemah (Allah menyatakan di dalam Alquran insân dhaîf yang artinya manusia itu lemah), maka tentunya semua hasil atau produk daripada kedaulatan rakyat/umat itu selalu pula tidak dapat dijamin kebenarannya setiap waktu. Apalagi apabila ada eksesekses atau overacting yang lucu-lucu, sehingga dengan begitu tidak pula dapat dikatakan, bahwa kedaulatan rakyat itu selalu mengandung kekuasaan yang mutlak/ absolut benar. Dan karena yang mutlak benar itu adalah Allah, maka kedaulatan rakyat/umat itu, jika mau benar dan baik haruslah disesuaikan dan diarahkan kepada isi, maksud dan tujuan dari kedaulatan Allah, yang berkekuasaan penuh sepenuh-penuhnya atau mutlak). ${ }^{11}$

Menurut ajaran Islam, sebagaimana dikemukakan oleh Kasman Singodimedjo, bahwa Allah Yang menciptakan dan Tuhan seru sekalian alam seisinya itu sungguh-sungguh mentolerir/mengizinkan adanya kedaulatan rakyat, adanya kedaulatan negara dan adanya kedaulatan hukum, yang tentunya di dalam arti terbatas, yaitu di dalam batas-batas keizinan Allah ${ }^{12}$. Ekspresi berdaulatnya Allah tercermin dalam Q.s. alAhzâb [33]: 36 yang dapat diartikan bahwa jika Allah dan Rasul telah menetapkan suatu perkara (hukum), maka seorang mukmin atau mukminat tidak boleh menetapkan ketentuan lain menurut keinginannya sendiri. Pendapat Kasman Singodimedjo yang tercermin dalam Q.s. al-Ahzâb [33]: 36 tersebut menunjukkan bahwa meskipun kedaulatan yang berarti rakyat yang berdaulat dalam arti rakyat yang mempunyai kekuasaan, tetapi masih ada yang lebih berdaulat atau berkuasa yaitu Allah Swt. Di sini suara rakyat bukanlah suara Tuhan, karena rakyat dapat saja melakukan perbuatan yang tidak sesuai dengan syariat.

Dengan demikian, dalam Islam kekuasaan politik hanya memiliki wewenang hukum untuk membuat produk hukum sebagai upaya menjalankan syariat. Persoalan kemudian adalah bagaimana Allah mengekspresikan kedaulatan-Nya di dunia nyata. Alquran menegaskan bahwa manusia di bumi adalah khilafah (pengganti) Allah dengan tugas memakmurkan bumi dan kekuasaan yang dimiliki adalah amanah. Oleh karena itu dalam Islam, kedaulatan Tuhan merupakan sumber dari segala kedaulatan.

Dalam pandangan Islam, kekuasaan yang dimiliki umat Islam bukanlah hak bawaan mereka sendiri, melainkan amanat dari Allah. ${ }^{13}$ Demikian juga

${ }^{11}$ Kasman Singodimedjo, Masalah Kedaulatan, (Jakarta: Bulan Bintang, 1978), h. 40.

${ }^{12}$ Kasman Singodimedjo, Masalah Kedaulatan, h. 24.

${ }_{13}$ Muhammad Asad, "Pemerintahan Islam dan Asas-Asasnya", dalam Salim Azzam (Editor), Beberapa Pandangan Tentang Pemerintahan Islam, terjemahan Malikul Awwal dan Abu Jalil, (Bandung: Mizan, 1983), Cetakan pertama, h. 80-81. 
Muhammad A. Al-Buraey menyatakan bahwa:

Pemerintahan dan penguasa hanya untuk Allah dan harus sesuai dengan syariat, tidak ada seorang pun atau kelompok yang memiliki hak untuk mengingkari Tuhan, kedaulatan hanya untuk Allah semata, legislasi juga hanya untuk Allah, sehingga pemerintahan negara Islam memperoleh keabsahannya hanya dengan melaksanakan hukum-hukum Allah atau syariah-Nya. ${ }^{14}$

Beberapa ayat Alquran yang menjadi dalil dan landasan bahwa kedaulatan rakyat bersumber pada hukum Allah adalah Q.s. Fâthir [35]: 16-17, Q.s. alMa’ârij [70]: 40-41 dan Q.s. al-Furqôn [25]: 36-39

Dengan demikian, dipertegas oleh Kasman Singodimedjo bahwa:

Mengenai kedaulatan rakyat atau kedaulatan ummat, maka sesungguhnya rakyat atau umat itu tidak dapat dikatakan berdaulat di dalam arti berkuasa penuh, karena rakyat/ummat itu tetap saja terdiri atas manusiamanusia yang sifatnya daif atau lemah sebagai makhluk. ${ }^{15}$

Oleh karena rakyat atau umat tidak dapat berkuasa sepenuhnya dan mereka merasa perlu untuk memilih pemimpin di antara mereka secara bersama yang kemudian diwakilkan kepada para wakilnya yang akan duduk di pemerintahan, baik di legislatif maupun di eksekutif. Wakil-wakil rakyat tersebut harus menyalurkan aspirasi rakyat, aspirasi rakyat yang tentu yang sesuai dengan syariat, yang berarti pemimpin itu telah sungguh-sungguh hanya bertugas atas nama rakyat/umat yang sejalan dengan kehendak Tuhan.

Dengan demikian, dikenallah pemilihan untuk memilih wakil-wakil rakyat/umat di antara mereka. Maka di dalam sejarah kebudayaan Islam sebenarnya sudah mengenal metode atau cara untuk memilih pemimpin umat, yang berbeda dengan metode yang sekarang dikenal yaitu pemilihan umum sebagai implementasi kedaulatan yang dimaksud menurut versi demokrasi Barat.

\section{Sejarah Pemilu dalam Peradaban Islam}

Pemilu dalam sejarah peradaban Islam ditemukan dari peristiwa yang mengarah pada bentuk sebuah pemilu yang kemudian dijadikan landasan oleh para ulama sekarang untuk membenarkan pemilu yang saat ini dipraktekkan. Misalnya Baiat al-Nuqabâa (wakil-wakil suku), yaitu ketika kaum Anshar membaiat Nabi Saw. di 'Aqabah. Saat itu, Nabi Saw. bersabda bahwa pilihlah untukku dari kalian dua belas orang wakil yang akan menunaikan apa-apa yang

${ }^{14}$ Muhammad A. Al-Buraey, Islam Landasan Alternatif Administrasi Pembangunan, Terjemahan Achmad Nashir Budiman, (Jakarta: Rajawali Press, 1986), Cetakan Pertama, h. 157.

${ }^{15}$ Kasman Singodimedjo, Masalah Kedaulatan, h. 54. dibutuhkan oleh kaum mereka. ${ }^{16}$ Selanjutnya dalam kisah utusan Hawzan, bahwa utusan Hawzan datang kepada Rasulullah Saw. dalam keadaan Muslim dan memberi baiat. Ia memohon kepada Nabi Saw. agar mengembalikan harta mereka (yang dirampas karena perang). Nabi pun minta persetujuannya (kaum muslimin) tentang hal itu dan mereka memberikan isyarat keridaan. Akan tetapi Nabi tidak cukup dengan persetujuannya saja, selanjutnya Nabi bersabda bahwa Kami tidak mengetahui siapa yang mengizinkan kalian tentang demikian dan siapa yang tidak mengizinkan. Pulanglah, hingga masalah ini diangkat (diadukan) kepada kami oleh wakil yang kalian tunjuk. ${ }^{17}$

Dua riwayat tersebut dijadikan alasan atau dasar oleh para ulama sekarang terhadap persoalan pemilihan umum, karena kedua riwayat tersebut mempunyai makna mengenai persoalan kedaulatan rakyat, yaitu rakyat memberikan pilihannya kepada mereka yang mewakilinya.

Begitu juga periode sesudah Nabi Saw., yaitu pada masa al-Khulafầ al-Râsyidûn. Pemilihan al-Khulafầ alRâsyidûn berbeda dengan metode pemilu yang dikenal sekarang. Pemilihan umum yang dikenal pada masa alKhulafầ al-Râsyidûn dapat ditemui janji setia (baiat) dari masing-masing khalifah yang terpilih. Janji setia (baiat) dilaksanakan di masjid kemudian rakyat memberikan baiat kepada khalifah, sehingga di sini ada keterlibatan dan peran rakyat dalam baiat khalifah.

Pada saat pemilihan Abû Bakr yang dilakukan di balai pertemuan Bani Saidah oleh kelompok kecil yang terdiri atas lima orang selain Abû Bakr, yaitu 'Umar ibn al-Khaththâb, Abû Ubaydah ibn Jarah, Basyîr ibn Sa’ad, Asid ibn Khudayr dan Sâlim, seorang budak Abû Khudzayfah yang telah dimerdekakan. ${ }^{18}$ Kelima orang itu merupakan perwakilan dari kelompok Muhajirin (suku Quraisy) dan kelompok Anshar masingmasing dari unsur Khazraj dan Aus. Hal ini berbeda dengan 'Umar ibn al-Khaththâb yang terpilih tidak melalui proses pemilihan sebagaimana Khalifah Abû Bakr. Meskipun demikian, 'Umar ibn al-Khaththâb menyatakan ketika sampai kepadanya berita bahwa orang-orang berkata bahwa jika 'Umar meninggal dunia mereka akan memberikan baiat pada si Fulan. Beliau juga melarang bahwa barangsiapa membaiat seorang pemimpin tanpa proses musyawarah, baiatnya dianggap tidak sah, dan tidak ada baiat terhadap orang yang mengangkat baiat terhadapnya atau keduanya harus

${ }_{16}$ Dikutip ulang oleh Rapung Samuddin, Fiqih Demokrasi, Menguak Kekeliruan Pandangan Haramnya Umat Terlibat Pemilu dan Politik, (Jakarta: Gozian Press, 2013), Cetakan Pertama, h. 304-305.

${ }^{17}$ Rapung Samuddin, Fiqih Demokrasi, h. 304-305.

${ }^{18}$ Munawir Sjadzali, Islam dan Tata Negara, Ajaran, Sejarah dan Pemikiran, (Jakarta: UI Press, 1993), h. 23. 
dibunuh. ${ }^{19}$ Riwayat ini adalah bentuk dari pemilihan umum yang dikenal pada saat itu melalui mekanisme musyawarah dengan rakyat dan mengembalikan urusan pemilihan pemimpin kepada rakyat (kaum muslimin).

Riwayat selanjutnya adalah perbuatan 'Abd al-Rahmân ibn 'Awf ketika bermusyawarah dan meminta pendapat rakyat untuk menetapkan siapa yang laik menjadi seorang khalifah setelah 'Umar ibn al-Khaththâb wafat. Diwirayatkan bahwa 'Abd al-Rahmân ibn 'Awf selama tiga hari bermusyawarah dan meminta pandangan rakyat hingga mantap pilihan jatuh pada 'Ustmân ibn 'Affân. Saat itu beliau berkata bahwa beliau melihat pilihan manusia tidak bergeser pada Utsmân. ${ }^{20}$ Riwayat 'Abd al-Rahmân ibn 'Awf ini menunjukkan peran dan keterlibatan rakyat dalam pemilihan khalifah. Begitu juga dalam pemilihan 'Alî ibn Abî Thâlib, dipilih melalui pemilihan, meskipun banyak yang menentangnya. Pada saat 'Alî ibn Abî Thâlib terpilih, 'Alî ibn Abî Thâlib menolak jika baiatnya hanya sebagai baiat khusus dari abl al-hall wa al-áqdi. 'Alî ibn Abî Thâlib kemudian berdiri di dalam masjid dan rakyat berbondong-bondong memberikan baiat kepada beliau. ${ }^{21}$ Bentuk demikian merupakan bentuk pemilu karena adanya keterlibatan dan peran rakyat dalam menyukseskan baiat seorang pemimpin (khalifah).

Dengan demikian, pemilu dalam Islam dapat digambarkan yaitu: (1) Kandungan proses pemilu berupa keharusan tegaknya baiat atas pilihan dan rida rakyat, merupakan perkara yang tercakup dalam syariat. Baiat dalam Islam tidak terjadi melainkan atas asas pilihan, maka baiat yang terjadi pada seluruh al-Khulafấ alRâsyidûn, yang tegaknya berdasarkan rida dan pilihan. (2) Menyerahkan urusan baiat dan ketaatan kepada rakyat merupakan perkara yang diakui oleh syariat. Wajib bagi seluruh rakyat memberi baiat kepada imam (kepala negara) mereka. Karena baiat kemudian terikat oleh hukum-hukum dan kewajiban-kewajiban. ${ }^{22}$

Terdapat perbedaan antara pemilu yang terjadi di Indonesia saat ini dengan apa yang terjadi dalam Islam sebagaimana diriwayatkan di atas. Perbedaan tersebut adalah: (1)Menyerahkan urusan pemilihan kepala negara kepada seluruh rakyat, serta membatasinya pada orang yang mereka (rakyat) kehendaki. Hal ini tentunya tidak terdapat dalam Islam. Dalam sejarah Islam, pemilihan khalifah yang dilakukan oleh abl al-

${ }^{19}$ Hadis riwayat al-Bukhârî, Shahîh $\underline{h}$ al-Bukhârî, Bâb Rajm al- $\underline{H} u b l a ̂$ fì al-Zinâ Idzâ Ahshanat, No. 6830, sebagaimana dikutip oleh Rapung Samuddin, Fiqih Demokrasi, Menguak Kekeliruan Panangan Haramnya Umat Terlibat Pemilu dan Politik, (Jakarta: Gozian Press, 2013), h. 306.

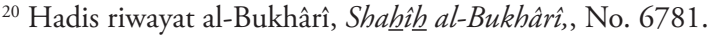

${ }^{21}$ Abû Ja'far al-Thabarî, Târîkh al-Thabarî, (Beirut: Dâr al-Fikr, 1997), h. 75.

${ }^{22}$ Rapung Samuddin, Fiqih Demokrasi, h. 308 - 309. ball wa al-'aqdi, kemudian diikuti oleh baiat seluruh rakyat, sebagaimana terjadi pada masa Abû Bakr atau keterlibatan manusia dalam baiat khalifah secara langsung tanpa ada pilihan dan pembatasan bagi mereka sebagaimana terjadi pada baiat 'Alî ibn Abî Thâlib. (2) Pemberian kepada setiap orang satu hak suara yang sifatnya terbatas, sebab dari perhitungan suara tersebut keluar siapa yang akan menjadi pemimpin berdasarkan suara mayoritas. Metode ini juga tidak terdapat dalam sejarah Islam. Baiat yang sifatnya umum terselenggara berdasarkan rida manusia dan kesediaan mereka memberikan baiatnya. Adapun baiat yang sifatnya khusus dari abl al-hall wa al-'aqdi terselenggara setelah melalui proses musyawarah dan pertimbangan tanpa memperhatikan perhitungan suara seperti pemilu hari ini. Kendati para fukaha menyatakan bahwa yang dikedepankan adalah pendapat mayoritas dan bukan selainnya, namun hal ini pun terbatas pada pendapat dan pandangan abl al-hall wa al-aqdi dan bukan pandangan umum sebagaimana terjadi hari ini. (3) Adanya calon-calon lain yang ikut bertarung untuk mendapatkan pilihan dan baiat dari rakyat. Padahal persoalan menyerahkan baiat kepada rakyat dalam sejarah Islam bukan untuk tujuan membedakan dan memilih calon-calon yang bertarung, akan tetapi untuk memberi baiat kepada khalifah yang dipilih oleh ahl al-hall wa al-'aqdi atau ikut serta (bersama abl al-hall wa al-'aqdi) dalam memberikan baiat kepada seseorang tertentu. ${ }^{23}$

\section{Perbedaan Sikap Ulama}

Sikap para ulama terhadap pemilu terbagi menjadi dua kelompok dengan pandangan yang berbeda. Kelompok pertama, yaitu yang mengharamkan pemilu sebagaimana dipraktekkan sekarang ini. Menurut kelompok ini, pemilu sekarang sudah tidak sesuai dengan syariah. Karena pemilu hukumnya tidak boleh atau haram, maka tidak boleh menempuh atau mempraktekkan metode pemilu dalam bentuk seperti yang dipraktekkan hari ini $^{24}$. Pendapat ini dikemukakan oleh Muhammad 'Abd Allâh al-Imâm,

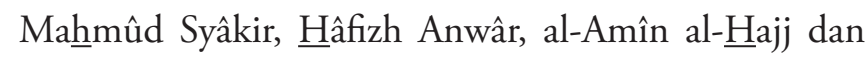
Muhammad ibn Sảad al-Ghâmidî. Ada beberapa alasan bagi kelompok ini untuk mengharamkan pemilu sebagaimana dipraktekkan sekarang ini (khususnya di Indonesia), seperti: (1) Pemilu yang dipraktekkan sekarang ini tidak dikenal dalam Islam karena tidak ada dalil-dalilnya. (2) Pemilu yang diselenggarakan menimbulkan kerusakan, tidak ada ketakwaan terhadap

\footnotetext{
${ }^{23}$ Rapung Samuddin, Fiqih Demokrasi, h. 309 - 310.

${ }^{24}$ Rapung Samuddin, Fiqih Demokrasi, h. 311.
} 
Allah Swt., penggunaan dana yang besar (pemborosan), sikap fanatik terhadap kelompoknya sendiri, jual beli suara dan mengelabui pemilih sehingga pelaksanaan pemilu banyak menimbulkan kemudaratan daripada manfaat. (3) Sistem pemilu legislatif dengan suara mayoritas tidak dikenal dalam Islam karena dalam Islam yang menjadi ukuran adalah sebuah kebenaran yang wajib diterima. (4) Tidak dipenuhi syarat-syarat orang untuk dipilih menjadi pemimpin karena sekarang ini semua orang mempunyai hak yang sama untuk dipilih. (5) Persamaan hak untuk memilih (persamaan mutlak tanpa ada perbedaan keahlian masing-masing) sehingga tidak sesuai dengan firman Allah dalam Q.s. al-Zumar [39]: 9 yang artinya "Adakah sama orang-orang yang mengetahui dengan orang-orang yang tidak mengetahui ? Sesungguhnya orang yang berakallah yang dapat menerima pelajaran”. (6) Aturan demokrasi yang diambil dari Barat sehingga merupakan aturan jahiliyah. (7) Dalam kenyataannya, tujuan dari pelaksanaan pemilu menghasilkan jabatan yang tidak mencapai kebaikan dan maslahat bagi masyarakat. (8) Tidak adanya perbaikan yang signifikan bagi kehidupan umat manusia.

Kelompok kedua berpandangan menghalalkan pemilu sebagaimana dipraktekkan sekarang ini karena masih tetap dalam koridor syariah. Kelompok ini berpendapat bahwa pemilu sebagaimana dipraktekkan sekarang ini hukumnya halal, selama metode pemilihan sesuai dengan syariah. Pendapat ini dikemukakan oleh mayoritas ulama kontemporer, seperti Muhammad Rasyîd Ridhâ, Abû al-A'lâ al-Mawdûdî, Yûsuf alQaradhawî dan 'Abd al-Qâdir Awdah. Ada beberapa alasan atau dalil yang membolehkan pemilu seperti sekarang ini, yaitu: (1) Inti sebenarnya dari baiat adalah pemberitahuan dari rakyat yang memberikan baiat akan persetujuan dan rida terhadap seseorang yang akan dibaiat, dan hal ini terwujud dalam pemilu hari ini $^{25}$. (2) Kenyataan dalam sejarah Islam dan riwayat Islam menunjukkan adanya sebuah proses pemilu. (3) Syariat Islam datang membawa pengakuan bagi peran dan rida rakyat dalam baiat serta tidak menetapkan batasan metode yang dengannya diketahui keridaan itu. Pemilu termasuk salah satu metode aktual yang digunakan untuk mengetahui keridaan rakyat. Disamping itu, tidak ada dalil yang menunjukkan pelarangan dan tidak pula yang membatasi metodenya dengan sarana-sarana tertentu. ${ }^{26}$ (4) Umatlah yang

25 'Abd al-Hâmid al-Anshârî, al-Âlam al-Islâmî bayna al-Syûrâ wa al-Dimuqrathiyah, (Cairo, Dâr al-Fikr al-Islam, 1922 H), Cetakan ke1, h. 30 dan 324.

26 Muhammad Ahmad Mufti, Mafâhîm Siyâsah Syariyyah, (Amman: Dâr al-Basyîr, 1418 H), h. 50, lihat pula Munîr al-Bayâtî, merupakan pemilik hak dalam pemilihan seorang hakim atau kepala negara. Jika demikian, maka bagi mereka hak terlibat secara langsung dalam pemilihan atau melalui wakil-wakilnya dari kalangan abl al-hall wa al-aqd. ${ }^{27}$ (5) Metode pengangkatan seorang khalifah atau kepala negara termasuk dalam kategori ijtihadiyah. Tidak ada dalil khusus yang membatasinya dengan satu metode tertentu, sebab ia berbeda menurut perbedaan tempat dan zaman. Dibolehkan menempuh metode apa saja dalam pemilihan pemimpin selama tidak bertentangan dengan nas-nas syarak. ${ }^{28}$ (6) Pemilihan umum merupakan metode aktual yang dengannya dapat diketahui pandangan rakyat secara adil dan obyektif. Mereka yang berbeda dengan metode ini tentu tidak memiliki dalil yang sahih. Ketika mereka ingin mengetahui tentang abl al-hall wa al-'aqd serta metode dan batasan yang digunakan untuk zaman sekarang, adakah cara selain metode pemilu? Bagaimana mereka menjamin perpindahan kekuasaan serta mencegah aturan-aturan politik dari kezaliman tanpa melalui proses pemilu. ${ }^{29}$ (7) Allah Swt. memuji kaum mukmin yang telah menyeru kepada yang makruf dan mencegah kemunkaran sebagaimana dalam Q.s. Âli 'Imrân [3]: 110 yang artinya: "Kamu adalah umat terbaik yang dilahirkan untuk manusia, menyuruh kepada yang makruf dan mencegah dari yang munkar, serta beriman kepada Allah", dan Q.s. Âli 'Imrân [3]: 104 yang artinya: "Dan hendaklah ada di antara kamu segolongan umat yang menyeru pada kebajikan, menyuruh pada yang makruf dan mencegah yang munkar. (8) Tidak mungkin seluruh umat menegakkan kewajiban dan tidak pula selain kewajiban kifầ. Hendaknya bagi mereka mengambil asas perwakilan, yaitu manusia menyerahkan kewajiban tersebut kepada wakil mereka. Masalah ini yang terjadi dan diwujudkan dalam pemilu yang dipraktekkan saat ini untuk memilih perwakilan rakyat kepada orang-orang yang akan menegakkan kewajiban kifâyah tersebut. ${ }^{30}$

\section{Fatwa MUI tentang Haramnya Golput}

Majelis Ulama Indonesia (MUI) mengeluarkan fatwa haram untuk golput atau tidak menggunakan hak pilih pada saat pemilu. Fatwa tersebut dikeluarkan pada tanggal 25 Januari 2009, ketika Majelis Ulama

\footnotetext{
al-Nizhâm al-Siyâsî al-Islâmî, h. 178 dan 325.

${ }^{27}$ Munîr al-Bayâtî, al-Nizhâm al-Siyâsî al-Islâmî, h. 322 dan 325.

28 Shalâh al-Dîn Dabbûs, Al-Khalîfah Tawliyatuh wa Azluh,

(Iskandariyah: Muassasah al-Tsaqâfiyyah al-Jâmi'iyyah, t.t.), h. 243-244.

${ }^{29}$ Dâwud al-Baz, Al-Syûrâ wa al-Dimuqrathiyyah al-Niyâbiyyah, (Iskandariyah: Dâr al-Fikr al-Jâmi'̂̀, 2004) h. 153 dan 326-327.

30 'Abd al-Karîm Zaydan, Makalah al-Dimuqratiyah wa Musyârakah al-Muslim fì al-Intikhâbât, Majallah al-Majma' al-Fiqh al-Islâmî, Râbithah al-Âlam al-Islâmî, Edisi X, 1426 H, h. 58-59 dan 327.
} 
Indonesia melakukan sidang Ijtima ke-III yang digelar di Padang Panjang, Sumatera Barat. Berdasarkan hasil sidang yang dihadiri sekitar 750 orang ulama tersebut, disepakati lima point penting, yaitu: (1) Pemilihan umum dalam pandangan Islam adalah upaya untuk memilih pemimpin atau wakil yang memenuhi syarat ideal bagi terwujudnya cita-cita bersama sesuai dengan aspirasi umat dan kepentingan bangsa. (2) Memilih pemimpin dalam Islam adalah kewajiban untuk menegakkan imâmah dan imârah dalam kehidupan bersama. (3) Imâmah dan imârah dalam Islam menghajatkan syarat sesuai dengan ketentuan agama agar terwujudnya kemaslahatan dalam masyarakat. (4) Memilih pemimpin yang beriman dan bertakwa, jujur (siddîq), terpercaya (amânah), aktif dan aspiratif (tablìgh), mempunyai kemampuan (fathânah) dan memperjuangkan kepentingan umat Islam hukumnya adalah wajib. (5) Memilih pemimpin yang tidak memenuhi syarat-syarat sebagaimana disebutkan dalam butir 1 (satu) atau tidak memilih sama sekali padahal ada calon yang memenuhi syarat hukumnya adalah haram.

Fatwa tersebut kemudian diikuti dua rekomendasi, yaitu: (1) Umat Islam dianjurkan untuk memilih pemimpin dan wakil-wakilnya untuk mengemban tugas amar márûf nahy munkar. (2) Pemerintah dan penyelenggara pemilu perlu meningkatkan sosialisasi penyelenggaraan pemilu agar partisipasi masyarakat dapat meningkat sehingga hak masyarakat terpenuhi.

Setelah keluarnya fatwa MUI tersebut, banyak tanggapan pro dan kontra dari pelbagai kalangan. Ada yang sependapat dengan fatwa MUI itu dengan alasan agar ada wakil dari umat Islam yang duduk di DPR. Selain itu, ada pula pendapat yang tidak setuju dengan fatwa MUI tersebut karena golput berkaitan dengan hak memilih, bukan wajib memilih. Disamping itu, dengan keluarnya fatwa tersebut ada yang berpendapat bahwa MUI membenarkan praktek pemilu sekarang ini yang menimbulkan banyak kemudaratan. Mekanisme pemilihan pemimpin sudah menyimpang dari nilainilai syariah, bahkan dengan fatwa tersebut MUI telah melanggengkan bobroknya sistem politik di Indonesia.

Fatwa tersebut sebenarnya sebagai salah satu upaya dari MUI agar umat Islam memilih pemimpin yang memenuhi kriteria syar'i, meskipun pelaksanaan pemilu itu sendiri sudah sangat liberal dan menyimpang dari ajaran hukum Islam. Oleh karena itu, maka wajar jika banyak kalangan yang tidak mendukung adanya fatwa dari MUI tersebut.

Hal ini, meskipun mekanisme dan sistem pelaksanaan pemilu yang belum sesuai dengan syariah, tetapi setidaknya MUI telah memberikan peringatan kepada umat tentang pentingnya pemilihan umum untuk memilih perwakilan umat atau penguasa yang amanah sesuai dengan tuntutan Rasulullah Saw. Pemilihan umum di Indonesia yang merupakan praktek ketatanegaraan yang harus diselenggarakan untuk memilih pemimpin maupun perwakilan rakyat di lembaga perwakilan telah menimbulkan permasalahan. Dengan demikian, MUI memberikan jalan keluar (meskipun banyak juga yang tidak sependapat) agar umat Islam tidak terjebak dalam permainan politik yang dilakukan oleh kaum kafir yang tidak suka dengan Islam yang kemudian merugikan umat Islam.

Apabila mencermati pendapat di atas dengan memperhatikan pelaksanaan pemilu yang diselenggarakan di Indonesia, tentu dapat dilihat bahwa memilih wakil rakyat untuk melakukan tugas sesuai syariah dan dalam praktek ketatanegaraan berfungsi untuk melakukan

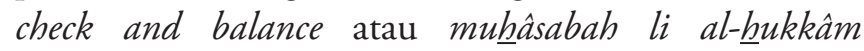
(mengoreksi penguasa), tentu saja hukumnya boleh. Hal ini karena pemilih memilih atau memberikan wakâlah kepada wakilnya untuk melakukan tugasnya diperbolehkan, mungkin juga hukumnya menjadi wajib. Begitu juga wakil rakyat yang dipilih dengan tugas membuat undang-undang dengan mekanisme yang dibenarkan dalam syariah, sehingga undang-undang yang lahir dari parlemen merupakan undang-undang yang dibenarkan oleh Islam. Mekanisme pembuatan undang-undang tidak didasarkan pada suara mayoritas, tetapi didasarkan pada pertimbangan dalil atau karena perintah wahyu. Berarti di sini suara rakyat bukanlah suara Tuhan, tetapi suara Tuhan-lah yang mengatur kehidupan umat manusia (rakyat).

Dalam hal mencermati rancangan undang-undang pemilihan kepala daerah yang baru saja disahkan oleh DPR, dengan opsi pemilihan kepada daerah melalui DPRD, sebenarnya sebagai upaya mengembalikan kembali proses demokrasi yang tidak individualistis. Pemilihan kepala daerah melalui DPRD setidaknya sudah mendekati kepada syariah, karena tidak mengorbankan rakyat banyak dengan segala kemudaratan yang dapat ditekan sekecil mungkin. Adapun rakyat yang mempunyai kedaulatan dapat mewakilkan kepada wakil-wakilnya yang ada di DPRD untuk mewakili dalam memilih kepada daerah. Hal ini juga dapat dikatakan demokratis menurut Islam dan tidak harus melalui rakyat secara langsung.

\section{Penutup}

Pemilu yang dipraktekkan di Indonesia, khususnya, dan di belahan dunia, pada umumnya, merupakan praktek ketatanegaraan yang harus dilaksanakan, 
yang selain sebagai implementasi kedaulatan rakyat juga berfungsi untuk memilih wakil-wakil rakyat dan memilih pemimpinnya. Akan tetapi apabila dikaji secara mendalam, praktek pemilu menurut hukum Islam sebenarnya sudah menyimpang dari ketentuan syariah, meskipun MUI telah mengeluarkan fatwa wajib hukumnya untuk memilih dan haram hukumnya apabila tidak memilih (golput).

Dalam pandangan Islam, pemilu adalah salah satu cara, bukan satu-satunya cara (uslîb) yang biasa digunakan untuk memilih wakil rakyat atau pemimpin. Hal ini, meskipun hukum asal pemilu itu sebagai uslîb adalah mubah (boleh), tetapi perlu diketahui bahwa pelaksanaan pemilu harus sesuai dengan ketentuan syariah. Dalam pemilu legislatif, uslûb itu digunakan untuk memilih wakil rakyat dengan tugas membuat undang-undang dan harus sesuai dengan ketentuan syariah, tidak berdasarkan suara mayoritas serta melakukan checks and balancies terhadap kekuasaan lainnya. Begitu juga dalam pemilihan kepala negara dan kepala daerah, uslûb ini digunakan untuk memilih orang yang memenuhi syarat sebagai pemimpin.

Dengan demikian, pemilihan umum dalam pandangan Islam dapat dipergunakan sebagai salah satu cara dalam kehidupan kenegaraan, apabila negara yang bersangkutan telah memilih jalan demokrasi sebagai satu-satunya dalam kehidupan berbangsa, bernegara dan bermasyarakat. Akan tetapi, demokrasi yang dimaksudkan adalah demokrasi yang sesuai dengan ketentuan syariah. []

\section{Pustaka Acuan}

A. Hassan, Al Furqon (Tafsir Al Qur'an), Jakarta: Tinta Mas, 1962.

Al-Buraey, Muhammad A., Islam Landasan Alternatif Administrasi Pembangunan, Terjemahan Achmad Nashir Budiman, Jakarta: Rajawali Press, 1986, Cetakan Pertama.

Anshârî, al-, 'Abd al-Hâamid, al-Âlam al-Islâmî bayna al-Syûrâ wa al-Dimuqrathiyah, Cairo, Dâr al-Fikr alIslam, $1922 \mathrm{H}$, Cetakan ke-1.

Asad, Muhammad, "Pemerintahan Islam dan AsasAsasnya”, dalam Salim Azzam (Editor), Beberapa Pandangan Tentang Pemerintahan Islam, terjemahan Malikul Awwal dan Abu Jalil, Bandung: Mizan, 1983, Cetakan pertama.
Asshiddiqie, Jimly, "Bung Hatta: Bapak Kedaulatan Rakyat", dalam Bung Hatta Bapak Kedaulatan Rakyat, Editor: Sri Edi Swasono, Jakarta: Yayasan Bung Hatta, 2002.

Asshiddiqie, Jimly, Islam dan Kedaulatan Rakyat, Jakarta: Gema Insani Press, 1995, Cet. Pertama.

Azzam, Salim, Beberapa Pandangan Tentang Pemerintahan Islam, Bandung: Mizan, 1983.

Bayâtî, al-, Munîr, al-Nizhâm al-Siyâsî al-Islâmî.

Baz, al-, Dâwud, Al-Syûrâ wa al-Dimuqrathiyyah alNiyâbiyyah, Iskandariyah: Dâr al-Fikr al-Jâmî̀̂, 2004.

Dabbûs, Shalâh al-Dîn, Al-Khalîfah Tawliyatuh wa Azluh, Iskandariyah: Muassasah al-Tsaqâfiyyah alJâmi'iyyah, t.t.

Departemen Pendidikan dan Kebudayaan Republik Indonesia, Kamus Besar Bahasa Indonesia, Jakarta: Balai Pustaka, 1991.

Hatta, Mohammad, Demokrasi Kita, Jakarta:Ghalia Indonesia, 1977.

Kementerian Urusan Agama Islam, Wakaf, Da'wah dan Irsyad Kerajaan Saudi Arabia, Al Qur'an dan Terjemahannya, Medina Al-Munawwarah: Percetakan Raja Fahd, 1418.

Mas'udi, Masdar Farid, Syarah Konstitusi UUD 1945 dalam Perspektif Islam, Jakarta: Alvabet, 2010.

Mufti, Muhammad Ahmad, Mafâhîm Siyâsah Syariyyah, Amman: Dâr al-Basyîr, 1418 H.

Samuddin, Rapung, Fiqih Demokrasi, Menguak Kekeliruan Pandangan Haramnya Umat Terlibat Pemilu dan Politik, Jakarta: Gozian Press, 2013.

Singodimedjo, Kasman, Masalah Kedaulatan, Jakarta: Bulan Bintang, 1978.

Sjadzali, Munawir, Islam dan Tata Negara, Ajaran, Sejarah dan Pemikiran, Jakarta: UI Press, 1993.

Thabarî, al-, Abû Ja'far, Târîkh al-Thabarî, Beirut: Dâr al-Fikr, 1997.

Zaydan, 'Abd al-Karîm, Makalah al-Dimuqratiyah wa Musyârakah al-Muslim fì al-Intikhâbât, Majallah al-Majma' al-Fiqh al-Islâmî, Râbithah al-Âlam alIslâmî, Edisi X, 1426 H. 